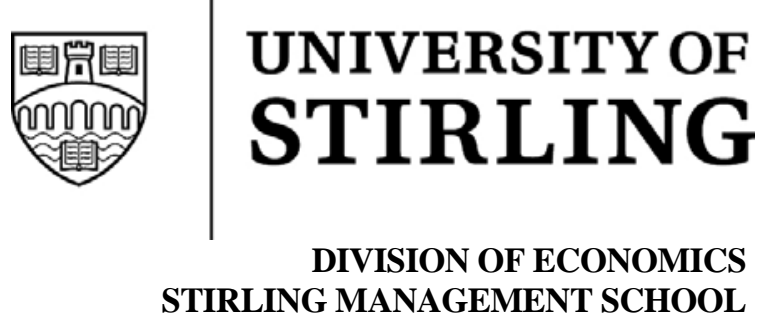

Did British women achieve long-term economic benefits from working in essential WWII industries

Robert A. Hart

Stirling Economics Discussion Paper 2009-05

February 2009

Online at http://www.economics.stir.ac.uk 


\title{
Did British women achieve long-term economic benefits from working in essential WWII industries?
}

\author{
Robert A. Hart \\ Department of Economics \\ University of Stirling and IZA \\ Stirling FK9 4LA \\ (email: r.a.hart@stir.ac.uk)
}

February, 2009

\begin{abstract}
Between mid-1939 and mid-1943 almost 2.2 million additional women were recruited into Britain's essential war industries. These consisted, predominantly, of young women recruited into metal and chemical industries. Much of the increased labour supply was achieved through government directed labour initiatives. This culminated, in January 1942, with the Control of Engagement Order whereby women between the ages of 18 and 40 who either entered the labour market or who changed employment were compulsorily directed into jobs and industries that were vital to the war effort. There were also many woman volunteers for such work, partly due to the fact that extreme labour scarcity drove up relative female wage rates. At least $42 \%$ of the $18-20$ age cohorts and $32 \%$ of the 21 25 age cohorts in 1943 worked in the essential industries. Two-thirds of those involved owed their jobs to wartime industrial expansion. The majority of such women entered a world of work that had been previously dominated by men. They obtained considerable training, job experience and pay advantages compared to subsequent age cohorts who were not eligible for war work. This bestowed on them subsequent labour market advantages that would otherwise not have occurred. Using a regression discontinuity design the empirical work shows that the long term earnings benefits of those age cohorts eligible for conscription, measured 30 years after the war, were in the order of between $2 \%$ and $9 \%$ higher than the age cohorts that followed them.
\end{abstract}

JEL Classification: J16, J24, J31, N44

Key Words: WWII female employment, essential war industries, long-term real wages, regression discontinuity design

Acknowledgements: Research was funded by ESRC Grant RES-000-22-2899. I am grateful to Sascha Becker, Paul Devereux, William Kenefick and George Peden for useful advice and to Elizabeth Roberts for research assistance. 


\section{Introduction}

There is a well established literature on the long-term earnings effects of male military service. The conclusion of Angrist (1990) in relation to the loss of earnings among white Vietnam war veterans is representative of wider findings. He states that "they earn less because their military experience is only a partial substitute for the civilian labor market experience lost while in the armed forces”. In the largest scale military conflicts, such as WWI and WWII, very significant proportions of young males within the main protagonist nations were required to undertake military service. Their withdrawal from, or unavailability for, civilian employment combined with major expansions of war supply industries caused severe labour shortages. One important solution was to recruit female substitute labour. For the large part, very significant numbers of young women entered a world of work previously dominated by men. They received training and work experience that, for most, would have been otherwise unavailable. This raises an interesting question. Contrary to the negative impact of the loss of civilian work experience suffered by males called-up to military duty, did the concomitant work experience gained by females produce positive long term labour market benefits for the affected age cohorts?

Between mid-1939 and mid-1943 almost 4 million British men joined the armed forces and the civil defence. Additionally, 530,000 women joined the auxiliary services and civil defence. The resulting losses of civilian employment, together with a significant expansion of manufacturing industry, created critical labour shortages. The most important strategy for tackling this problem was to recruit almost 2.2 million additional women into the essential war industries. In the early war period female employment 
growth resulted from voluntary war service, partly for patriotic reasons and partly due to significant real wage gains resulting from growing labour shortages. It was soon realised, however, that such supply was falling well short of projected demand. In early 1941, the government required women to register for employment. While this was an important step forward, it was not accompanied by adequate controls that ensured that as many women as possible filled strategic vacancies and remained working in essential jobs. Finally and most importantly, at the beginning of 1942 all young women entering the labour market or changing job were effectively conscripted into essential war work.

In mid-1939 the proportion of male to female industrial workers was 2.7 to 1 . By mid-1943 it had fallen to 1.6 to $1{ }^{1}$ The top-most of the essential wartime industries - socalled Group 1 industries - covered metals and chemicals. ${ }^{2}$ The female share of total employment between mid-1939 and mid-1943 rose from 15.4\% to 35.1\% in metal industries and from $24.8 \%$ to $51.1 \%$ in chemical industries. These reflected a combined growth in female employment numbers from 506,000 to 1,938,000.

The great majority of adult women employed in the essential war industries were young. As minimum estimates, $42 \%$ of $18-20$ year olds and $32 \%$ of $21-25$ year olds in

\footnotetext{
${ }^{1}$ See Ministry of Labour and National Service - henceforth referred to as MLNS - 1947, p.127.

${ }^{2}$ Up to 1943, the war-time industrial groups were classified into munitions industries, essential industries and less essential industries. From 1943 onwards, they were reclassified into Group 1, Group 2 and Group 3 industries. Group 1 and Group 2 industries covered the essential war requirements and were treated as covering the main labour and product market priorities. Group 1 consisted of metal manufacture, engineering, motors, aircraft and other vehicles, shipbuilding and ship repairing, metal goods manufacture, chemicals, explosives, oil etc. Group 2 covered agriculture, mining, national and local government services, gas, water and electricity supply, transport and shipping. Group 3 included food, drink and tobacco, textiles, clothing and other manufactures, building and civil engineering, distributive trades, commerce, banking, and other services.
} 
mid-1943 were so employed. While there were significant wartime rises in the participation of women over the age of 40 , older women tended to work in less essential industries. This allowed younger women in those industries to be redirected towards more vital war-related jobs. Other additional female recruitment derived from increases in the participation rates of married women and significant reductions in female unemployment.

Most women employed in the essential industries acquired general skills and onthe-job experience within manufacturing industry. A majority also entered sections of industry that before the war had been overwhelmingly dominated by male workers. The substitution of male by female labour was facilitated through the so-called process of labour dilution. Production processes were systematically broken down into job tasks defined over narrower ranges of skill requirements. By concentrating on a limited number of operations, women were able to perform skilled and semi-skilled job tasks after undertaking relatively short training periods. A sub-set of women, employed largely in the engineering industry, were trained to undertake highly skilled tasks that before the war had only been carried out by skilled, often fully-apprenticed, men. ${ }^{3}$

Women born in the second half of 1927 and later were not eligible to be recruited into wartime adult jobs. As early as 1946, female job opportunities in the essential industries significantly contracted and female rates of pay tended back towards pre-war

\footnotetext{
${ }^{3}$ In fact, there was an official distinction between 'women doing men's work' and 'women doing women's work' within wartime engineering (see, e.g., Inman, 1957; Hart, 2007). After a 32 week training period, the former largely performed skilled job tasks within jobs previously only undertaken by men (usually skilled apprenticed journeymen). The latter classification often included women who were the first to undertake specific engineering job tasks within given companies but tasks for which there were cases of women's input elsewhere.
} 
relative levels. Female post-war job growth largely took place within the less essential, poorer paid sectors such as textile, clothing and distributive trades. This war/post-war divide in the female labour market was reinforced by the fact that men returning from full-time military service were guaranteed their former civilian jobs. This sharp and sudden change in the fortune of women on the labour market provides an interesting natural experiment. On the one hand, age cohorts of young women, born largely between 1918 and 1927, had full access to the industrial world of men, a world consisting of relatively highly paid jobs and the acquisition of a wide range of general manufacturing skills. On the other, the female age cohorts that followed entered a job market that far more closely resembled the pre-war position of predominantly low paid service industry jobs with limited skill applications. This begs an important question. Did the unique training and work experience of young wartime women workers bestow long term labour market benefits compared to later female age cohorts who were not eligible for war service? Basing the test on subsequent real earning growth, and using a regressiondiscontinuity design, this paper attempts an answer.

\section{Female Employment in Essential War Industries}

Table 1 shows that from mid 1939 to mid 1943, there were net increases of about 2.2 million women employed in the essential Group 1 and Group 2 industries. ${ }^{4}$ Figure 1 shows female employment numbers between 1939 and 1945 in the Group 1 industries, a selection of Group 2 industries, and the Auxiliary services. Clearly, Group 1 metal

\footnotetext{
${ }^{4}$ Some categories of women workers were already deemed to be working in vital occupations and were exempted from war service, either auxiliary services or industrial participation. These included women with certain professional qualifications as well as nurses, midwives, and teachers.
} 
industries account for the greatest war-time expansion of female employment. ${ }^{5}$ Table 1 shows the share of female employment within total employment in the three industrial Groups at the beginning, middle and end of the war. Women display very significant rises in both share and employment numbers within Group 1 industries as well as in national and local government and in transport and shipping within Group 2 industries. Note that while women's share also increased in the less essential Group 3 industries their actual numbers declined due to the fact that these industries contracted during the war.

To what extent did state intervention account for such exceptional female employment growth rates? For the first year of war, there was no major shortage of available female labour. ${ }^{6}$ From January to July 1940, insured female employment grew by 322,000 divided equally between munitions production and other essential war industries. Up to this point, industrial recruitment was mainly on a voluntary basis. However, by December 1940 it was realised that - especially due to the continuing callup of men to the armed forces - the voluntary employment of women was inadequate. An estimated 2 million additional women workers were needed for the war effort. In March 1941, the Registration for Employment Order for women was issued and this led to 11.8 million women born in the years 1893 to 1927 being required to register for

\footnotetext{
${ }^{5}$ Between 1939 and the start of 1944, the numbers employed in Group 1 industries rose by about 2 million workers - from 3 to over 5 million - with the bulk of the increase accounted for by women. Over the same period, the number of men employed in Group 2 industries declined by 600,000 while women's employment rose by 800,000 (Ministry of Labour Gazette, 1944, p.197). Parts of these increases are accounted for by young women transferring from Group 3 industries.

${ }^{6}$ In fact, the percentage share of female within total employment in the immediate prewar years dropped monotonically from 30.4 in 1933 to 29.7 in 1938. In mid-1939 there were 257,000 women registered as unemployed.
} 
employment. ${ }^{7}$ Registration started in April 1941 and involved those born in 1920 and ended in July, 1945 in respect of women born in the first half of 1927 (see MLNS, 1947, pp. 42-44 and p. 337). Figure 3 shows that $60 \%$ or more women born between 1904 and 1926 were registered under the Order. ${ }^{8}$ Peak registration, at nearly $80 \%$, occurred for those born in 1919 and 1920.

The conscription of women into the auxiliary services and essential industries was introduced in the National Service (No.2) Act of December 1941. Unmarried women and childless widows aged 20 to 30 were made liable for call-up, amended to 19 to 30 in January 1943. Those conscripted were given the choice between the auxiliary services or civil defence or certain specified industrial jobs. ${ }^{9}$

While numbers of employed women rose substantially during 1941, as illustrated in Figure 1, labour supply growth rates fell well short of labour requirements. ${ }^{10}$ The Control of Engagement Order of January 1942 ensured that women leaving their existing jobs or entering the labour market were directed to jobs deemed to be essential to the

\footnotetext{
${ }^{7}$ In 1943, it was decided to register women up to the age of 51 and this turned out to be the final upper age limit.

8 The data in Figure 3 underestimate the true rates of registration. They relate to individuals who registered at or near the due date of registration. It is estimated (see Parker, 1957, p. 492) that if later registrations were included then the figures would increase by about one-twelfth.

${ }^{9}$ Where no preference was expressed then an eligible woman would be placed in industry. This form of conscription was suspended at the beginning of 1944 and reconstituted on a voluntary basis the next year.

${ }^{10}$ A manpower survey undertaken in mid-1941 estimated that an additional 922,000 women would be required by industry and the services by mid-1942 (Smith, 1984).
} 
national interest. ${ }^{11}$ Women between the ages of 20 and 30 - other than those with children under the age of 14 living with them - were obliged to obtain their employment through an employment exchange or an agency approved by the Ministry of Labour and National Service or a government approved employment agency. Added to this, if employers wished to recruit women covered by the Order then they were required to do so only through an approved agency. In May 1942 the Order was amended to cover 18 to 30 year olds and in February 1943 a further amendment extended coverage to 18 to 40 year olds. It was revoked in June, 1945.

Table 2 shows the net changes in the numbers of insured male and female workers (which exclude the armed forces and the auxiliary services) in the period 1942 to 1945 compared to 1937 . Very large reductions occurred among males aged between 18 and 35. Given that the data are adjusted for changes in the birth rates of these age cohorts ${ }^{12}$, it is safe to conclude that the vast bulk of the reductions were due to military call-up. The reductions are mirrored by increases in employment of females aged between 18 and 50 . These net female employment increases included (i) rises in married women’s participation rates $^{13}$, (ii) rises in the numbers of older women’s participation rates ${ }^{14}$, (iii)

\footnotetext{
${ }^{11}$ A major shortcoming of the earlier Registration of Employment Order was that there was no power to ensure that women who had been placed into essential jobs by a local employment office remained in those jobs. Also, it was possible for women themselves to find employment before the Ministry of Labour was able to interview them and place them into strategic vacancies (see Parker, 1957, p.287).

${ }^{12}$ As explained in the Table 2 notes, an allowance for the effect of changes in the birth rate on insured employment has been made. Figure 2 illustrates the especially large changes in male and female birth rates during WWI and the immediate years that followed.

${ }^{13}$ Only $10.4 \%$ of married women were employed in 1931, a figure that by the end of the war, in 1947, had risen to $18 \%$ (Smith, 1984).
} 
reductions in unemployment from 257,000 to 14,000 between 1939 and 1944 (MLNS, 1947, p.53).

Female wartime recruitment, either conscripted or voluntary, into the key Group 1 and Group 2 industries as well as the auxiliary services largely involved younger women. Table 3 compares employment growth rates of women aged 18-40 and those aged 41-59 between mid-1939 and mid-1943. There was a 460\% growth among the younger age band in Group 1 industries and the auxiliary services over the four years. There was a 92\% rise in younger female employment in Group 2 industries. By contrast, the younger age band displayed a 24\% reduction in employment in the less essential Group 3 industries. There was also growth in employment among 41-59 year olds in the essential industries but on a much smaller absolute scale than their younger counterparts. Moreover, there was a 45\% employment increase in the older group within Group 3 industries. The stark contrast between negative younger and positive older female growth rates in Group 3 industries reflected an overt government policy of allocating more pressing war supply jobs towards younger women with older women filling the Group 3 employment gaps. ${ }^{15}$

How significant was Group 1 and Group 2 industrial employment among young females by 1943, marking the peak of industrial activity? Table 4 provides estimates by

\footnotetext{
${ }^{14}$ This can be inferred from Table 2 for the 41 to 51 age groups. The expansion also occurred among 51 to 60 year-olds (see MLNS, 1947, p. 260).

${ }^{15}$ Younger women were directly withdrawn from less important jobs to work within the essential industries. Examples, including the movement of women from retail distribution, are given in ILO (1946, pp. 18-20). Transfers from Group 3 industries to work in the munitions factories occurred 'on a very large scale'(Ministry of Labour Gazette, December, 1947, p. 197).
} 
5 age bands for the period mid-1939 to mid-1943 within the 18 - 40 age range. I estimate that, in mid-1943, at least $42 \%$ of 18 - 20 year olds - i.e. women born between 1923 and 1925 - worked in these essential industries and that at least $27 \%$ of this birth cohort band owed their employment to the wartime expansion of these industries. Respective figures for the $21-25$ year olds are $32 \%$ and $21 \%$. Due to the fact that mainly young women were conscripted to work in the essential industries, these are almost certainly lower bound estimates with 'true' percentages probably considerably higher. ${ }^{16}$

\section{The Relative Benefits of the Wartime Female Labour Market}

What were the potential economic advantages to economically active women who were either subject to compulsory wartime employment orders or who volunteered for essential war work compared to subsequent female age cohorts who were not eligible? The former group enjoyed three kinds of comparative labour market advantages; viz. enhanced job prospects, greater opportunities to acquire saleable skills, and higher relative pay.

\section{(i) Job opportunities.}

Women conscripted into wartime employment had significantly more job opportunities in Group 1 and Group 2 industries than women entering adult employment

\footnotetext{
${ }^{16}$ Using the age ranges shown in Table 4 - i.e. 18-20, 21-25 etc. - I have estimated (a) the 18-40 year old 1943 employment totals and (b) 1939 - 1943 employment changes in Group 1 and Group 2 industries (see notes to Table 4). Weighting is derived from each age range's share of total insured employment in 1943. Almost certainly, however, this understates the weights of the 18 - 30 employment numbers and overstates the older 30 40 numbers because we know that employment in these industries was biased towards the youngest age groups. In other words, greater accuracy is dependent on dividing total insured employment by age into Group 1 and Group 2 industries on the one hand and Group 3 industries on the other. Requisite data are not available.
} 
after the war. The war years marked a substantial increase in female employment within these industries, both in absolute numbers and in the share of total employment. By contrast, Table 1 reveals that immediately after the war, by December 1946, there were large reductions in female job numbers and job shares in all of these industries. The decline was especially acute in the Engineering Industry where, by January 1947, 58\% of women employed in 1943 had been made redundant (Smith, 1984). ${ }^{17}$ In 1945, women comprised 31.8\% of the labour force in motor vehicles, cycles and aircraft (construction and repair) manufacture, a share that reduced to between $14 \%$ and 15\% during the 1950 s (Hart, 2007). ${ }^{18}$ At the same time, Table 1 shows large absolute increases in male employment within Group 1 and 2 industries immediately following the war. A major cause of the switch towards male employment was the Reinstatement of Civil Employment Act of 1944 which basically gave men and women called up for whole-time armed service the right to regain their pre-conscription civilian job (see MLNS. 1947, pp 159/9 for more details). Another reason was that a high proportion of women wartime

\footnotetext{
${ }^{17}$ Smith identifies two contributory factors. First, women who had directly substituted for men in wartime engineering employment were relatively well paid (see below in main text) and employers were keen to transfer them back to traditional women's jobs at about one-third of their former pay rates. Second, the dominant union, the Amalgamated Engineering Union, reached agreement in 1944 with the main employers' federation, the Engineering Employers' Federation, that any post-war redundancies would first impact on women doing men's work.

${ }^{18}$ It is not possible with these data to ascertain relative female employment changes in these industries on a cross-section geographical basis. For example, Acemoglu, Autor and Lyle (2004) find that, in the United States, women's labour force state-level participation in the immediate post-war was positively related to the fraction of working age men in each state who had served in the military during the mid 1940s.
} 
workers wanted to return to domestic life at the end of the war. ${ }^{19}$ Certainly, as can be inferred from the 1945 - 1947 surge in birth rates among 20-29 year-old women in Figure 4, the desire to have children played an important role in this respect. ${ }^{20}$

\section{(ii) Skill acquisition.}

Especially within Group 1 metal industries, women acquired job skills that before the war were either solely or largely in the preserve of male workers. From 1940 onwards, there were exceptionally severe skill shortages in engineering and other metalbased industries. The immediacy and pressing nature of the war demands meant that most women did not train for longer than 8 weeks. In this respect, and especially in relation to skilled trades, they could not act as direct substitutes for the men they replaced. Yet, equivalent output was required. The leading solution to this problem was to revise radically production methods and work organization. Broad production processes, traditionally covered by skilled male workers with long training and work experience, were broken down into more compartmentalised sub-processes. This had two effects (Inman, 1957). Some women were trained over short training periods to perform skilled, but narrower, job tasks. ${ }^{21}$ Others undertook job tasks classified as semi-skilled labour that had traditionally been undertaken by skilled men but had now been newly

${ }^{19}$ Smith (1984) cites evidence from a survey conducted by the Ministry of Reconstruction in late 1943.

${ }^{20}$ Therefore, a significant proportion of births at this time involved mothers with work experience. Using United States' cross-sectional data, Fernández, Fogli and Olivetti (2004) find that the sons of such women tend to marry women who are significantly more likely to work. While this is an interesting inter-generational effect, it would not be expected significantly to alter the findings here because it is the direct wartime experience itself that is held to be crucial.

${ }^{21}$ In engineering, such women undertook a 32 week training programme and were officially classifed as ‘women doing men's work' (Hart, 2007). 
identified through the process breakdowns. These developments were aided and abetted on the production side by major developments in the design and application of automatic and semi-automatic machines (ILO, 1946). Production reorganisation, and accompanying job reclassification and deskilling, were universally referred to as labour dilution (see Parker, 1981). ${ }^{22}$

While there are no direct data on the degree of skill acquisition among women during the war, indirect evidence points to it being substantial. Between June 1939 and December 1943, women employed in engineering and allied industries rose from 411,200 (18\% of total employment) to $1,544,000$ (39\%). In June $1940,75 \%$ of women employed in these industries were classed as either skilled or semi-skilled. Yet, despite the substantial growth in female employment between $84 \%$ and $85 \%$ were classed as skilled or semi-skilled from 1942 to 1944 (Inman, 1957, pp. 78/9). ${ }^{23}$ More generally across Group 1 industries, while women's job tasks ranged from those that required weeks of concentrated training to those requiring less than one hour learning-time, most women gained experience, for the first time, of a factory-floor work environment within

${ }^{22}$ Sheet metal working provides a well documented example of the dilution process (see Inman, 1957, pp. 60/1). It concerns the engineering of thinner varieties of metal plate and was a vital war-related production activity, with essential applications in aircraft, vehicle and ship building. A sheet metal worker cuts out, bends, and beats metal into shape (panel beating) and also laps, rivets and solders joints. These are skilled jobs requiring significant on-the-job experience and know-how. However, both during and immediately before the war, technical change facilitated deskilling. Traditional skilled manual processes involving hand and bench tools were increasingly replaced by power presses and automatic tools which could be operated by less skilled labour. Even where traditional skilled work was retained - for example, in the use of free hand methods in the shaping of metal - associated operations (like drilling and riveting) could be carried out by semi-skilled workers. Those engaged in pressing, drilling and riveting performed relatively narrow and repetitive tasks.

${ }^{23}$ Inman reports that approximately the same female skill percentage figures hold for the aircraft and motor industries. 
engineering and manufacturing plants. ${ }^{24}$ Apart from extensive on-the-job training and some formal training courses within companies, about 147,000 women completed engineering-related training courses with Government Training Centres and Technical Colleges during the war (Parker, 1957, Ch. XXII and Inman, 1957, Chapter III). Long-term efficiency gains within manufacturing industry derived from the process of labour dilution. For example, the identification of semi-skilled tasks within previously broadly defined skilled job descriptions helped to reduce unit costs and allow for better matching of skilled training to strictly skilled labour requirements. But this type of efficiency gain almost certainly benefited the more modern, less unionised, metal industries in the post-war period. These were mainly located in the Midlands and South of England. Many employers simply reverted back to the old methods after the war. In any event, as we have already seen, females entering the post-war labour market had for less access to these wartime-created job descriptions.

\footnotetext{
${ }^{24}$ As one of a wide range of examples, take the description of Douie (1950, p. 99) of females engaged in wartime metal manufacture. "The employment of women in the heavy iron and steel industry was rare in peace-time, but during the war women were to be found in practically every branch of the metal working industry. In September, 1942, they already constituted over 13\% of the industry, in which they were doing 950 different jobs. Some were steel smelters and iron pudlers. Others drove overhead electric cranes carrying huge cauldrons of molten metal from the furnaces to the moulding sheds. Some worked as hot and cold sawyers, straighteners and circular plate burners. One of the most skilled jobs was that of the deseamers, whose work it was to burn away defects in steel billets by means of the flame of an oxy-ferrolene jet.” In general, Douie (pp. 93-103) provides a succinct and evocative account of women's job tasks, range of skills, and relative importance within the wartime munitions, aircraft (construction and repair) and general (heavy and light) engineering factories. The scope of women's wartime employment in engineering and shipbuilding is also detailed by the ILO (1946) together with related information on women performing heavy work, the use and development of labour-saving devices as well as the roles of work dilution and skill acquisition.
} 


\section{(iii) Relative pay.}

Not only did 18 mark the minimum age that women were subject to the Control of Engagement Order but it also was the starting age at which adult rates of pay applied. In fact, for many women the wartime trends in adult pay almost certainly resulted in increased voluntary labour supply to Group 1 industries. The reason for this is that female earnings rose strongly relative to male earnings in the essential war industries. Table 5 shows percentage increases in men's and women’s earnings between October 1938 and January 1944 in (predominantly) Group 1 industries. While women’s rates of pay were generally lower than male equivalents throughout these industries, the relative increases in favour of women are reflected in the fact that the differentials were narrowing.

Using detailed Engineering Employers’ Federation (EEF) data on piece rates and hourly wage rates, Hart (2007) examines pay differentials in four core engineering sections in which women played prominent wartime roles - aircraft manufacture, light general engineering, heavy general engineering, and motors. ${ }^{25}$ In the run-up to war, from 1935 to 1939, female-male wage ratios (piecework and timework) declined slightly across these four sectors. In 1935, they lay in the range 0.44 to 0.55 and by 1939 they were in the range 0.42 to 0.51 . Weekly earnings ratios were lower and declined more steeply due largely to the fact that, approaching the war, men's weekly hours grew relative to women’s. By contrast, all female-male wage and earnings ratios grew steeply

\footnotetext{
${ }^{25}$ Between 55\% and 95\% of women doing women's work in these sections were paid piece rates. In aircraft and motors, piece work was also prevalent among women doing men's work while slightly more than $50 \%$ of women in general engineering were paid time rates.
} 
between 1940 to 1942 . The following examples are generally representative. Femalemale wage ratios among timeworkers in aircraft manufacture grew from 0.53 to 0.81 for women doing men's work and from 0.48 to 0.65 for women doing women's work. For piecework in heavy engineering the wage rates rose from 0.57 to 0.83 for women doing men's work and from 0.48 to 0.64 for women doing women's work. Earnings ratios also grew very significantly over this time. However, by 1951, all ratios fell back about $30 \%$ though they did stay significantly above their 1935 levels.

For one group of women - those officially classified as doing men's work within engineering sections - there was an unequivocal pay incentive. The EEF and the main engineering unions agreed that women doing men’s work should receive, after a 32 week probationary period during which wage rates were scaled upwards, the same basic wage rate and bonus applicable to their male equivalents. ${ }^{26}$

The main issue arising from this background is whether the relative labour market benefits experienced by women during wartime persisted into the longer term future. Did their unique training and industrial work experience give them a comparative advantage in later post-war rounds of recruitment and job promotion? Did their experience of work environments formerly dominated by men, and the concomitant pay scales that more closely reflected those of men, alter their longer term job and pay aspirations? Did these factors combine to give relative labour market advantages compared to women who in

\footnotetext{
${ }^{26}$ There were caveats to this agreement, such as equal pay would not apply if women needed special supervision. This type of proviso led to many contentious industrial relations problems (Smith, 1981; Inman, 1957 Chpt. 3; Dioue, 1950, pp. 117-119.) As a minimum, however, women undertaking men's work were paid no less than $75 \%$ of a men's pay rates.
} 
the immediate post-war years experienced far fewer vocational training opportunities and much narrower ranges of potential work experience?

\section{Data}

I begin by reviewing the three data sources on which long term real wage outcomes are based before discussing two important aspects of sample coverage. One common feature is that all wage and earnings measures are deflated by the British Retail Price Index.

New Earnings Survey Panel Data (NESPD)

The NESPD is an employer survey of individual-level data obtained from company payrolls. It comprises a random sample of $1 \%$ of the British workforce. Sampling is based on National Insurance numbers with the same individuals in the sample each year. Estimation here is based on the resulting panel from 1975 to 2001. Employers are legally obliged to provide the payroll information which refers to a given week in April of each year. Accordingly, there is a high response rate. ${ }^{27}$ Statistics refer, principally, to earnings and hours of work and given they are taken directly from payroll records they are considered to be very accurate. This paper makes use of the basic or standard weekly wage, defined in the NESPD as "gross weekly earnings excluding overtime divided by normal basic hours for employees whose pay for the survey period

\footnotetext{
27 The survey does not capture each and every year all of the individuals included in the sampling frame. It is based on current tax records and so, for example, individuals may not have an up-to-date record if they have recently changed jobs. However, a more serious problem of non reporting involves low-wage females (see below). I investigate the implications of, and correct for, this latter potential bias in the analysis that follows.
} 
was not affected by absence”. Estimation was also undertaken using hourly wage earnings (including overtime) to replaced standard hourly wages but this produced no substantive changes.

I exclude observations indicating earnings of less than £1 per hour (in 2001 pounds) and weekly hours in excess of $84 .^{28}$ The data embrace both full-time and parttime workers with the latter comprising about $40 \%$ of females.

\section{General Household Survey (GHS)}

The GHS is a continuous national survey of people living in private households, conducted on an annual basis by the Office for National Statistics (ONS). It started in 1971 and has been carried out since then, except for breaks in 1997-1998 when the survey was reviewed and in 1999-2000 when the survey was redeveloped. Unlike NESPD, the GHS is not a panel but rather a set of repeated cross-sections. Being a household survey, the GHS is subject to non-response and reporting error. The average response rate for the GHS during the periods incorporated here is $82 \%$, although with very little year-to-year variation. The weekly earnings data in the GHS are probably inferior to NESPD due to mis-reporting, non-response, and changes over time in the exact definition of earnings. I use the 1972 - 1978 GHS surveys for present purposes. ${ }^{29}$

\footnotetext{
${ }^{28}$ The lower wage bound exclusion is similar to that of Card (1999). It involves a loss of 740 female observations (from a sample of over 320,000 ) with wages less than $£ 1$. The minumum hourly wage was $£ 3.70$ in 2001 . There are 84 cases indicating weekly hours in excess of 84.

${ }^{29}$ Pre-1979 the GHS survey adopts different earnings measurements than later periods.
} 
UK Family Expenditure Survey (FES)

The FES is a voluntary survey of a random sample of private households in the United Kingdom carried out by ONS. It is a survey of household income as well as expenditures on goods and services. The survey started in 1957 with the purpose of providing information on spending patterns in the UK for use in the Retail Price Index. There is about a $60 \%$ response rate. Data are collected throughout the year to cover seasonal variations in expenditures. In addition to expenditure and income data, the FES provides details of the socio-economic characteristics of the households covered, including composition, size, social class, occupation and age of the head of household. I use FES data from 1970 to $1981 .^{30}$

\section{Sample coverage and age ranges}

In the first instance, I show results in respect of data samples covering birth years that are \pm 10 years of the pivotal birth year at which the Control of Engagement Order ceased to apply. I use samples of females born between 1917 and 1937, with mid-1927 marking the dividing line between eligibility under the Order and non-eligibility. For this initial design, I use age-ranges of females from 40 to 60. The upper age limit marks the official age of retirement for women. The relevant start years for each data series are 1975 (NESPD), 1972 (GHS), and 1970 (FES) and so the minimum observed age of those eligible is 42 .

\footnotetext{
30 The start year is 1970 because (a) in 1969 there was a significant reduction in sample size (to about $1 / 8^{\text {th }}$ of other years) with reported mean weekly earnings less than one-half of 1968 and 1970, (b) there is a gap from 1963-68 and (c) there are no available hours data for the earliest years. The end year is 1981 because prior to 1982 hourly earnings data include overtime hours but these are excluded in later years.
} 
I then extend the analysis in two directions. First, I experiment with other age cohort intervals - in the range of \pm 3 years to \pm 12 years. Since, for example, I show that greater proportions of young adult females worked in essential industries then it may be the case that long-term real earnings differences are accentuated within narrower ranges of age cohorts around the 1927 pivotal birth year. Suppose for example, I wish to concentrate on a comparison of women who were aged 18-21 between 1942 and 1945 amd between 1945 and 1948 then this would mean concentrating interest on \pm 3 years on either side of the $19271 \frac{1}{2}$ dividing period. Second, I test for the effects of narrowing the female age band to $40-55$ in the wage data. Thus, while keeping my sample sizes of pre- and post- 1927 age cohorts relatively large, this moves me more towards Haider and Solon (2006) who show that in the U.S. current income is a reasonable proxy for lifetime income for men between their mid-30's and late 40's.

I concentrate on the NESPD for these extensions. The sample sizes of GHS and FES are small, and the precision of the estimates are weak, when I cut down the lengths of the age cohorts to 3 and 6 years on either side of the 1927 pivotal birth cohort.

\section{Adjusting for Effects of Low-Paid}

The NESPD under-reports individuals who earn less than the Pay As You Earn (PAYE) tax threshold in Britain and so are not subject to tax. This is potentially serious problem in respect of women. This can be seen in Table 6 by comparing proportions of females below the thresholds in the NESPD with those of the GHS, a survey that reasonably accurately represents the true incidence of low pay under this definition. Note that the GHS, unlike the NESPD, exhibits relatively little year-to-year variation in the 
proportions of women under the threshold. About one-quarter of the GHS-reported female workforce earn less than the PAYE threshold. Not only do the NESPD proportions consistently fall well short this fraction but they also display considerable variation through time. Under-reporting of the low paid is especially acute in the early years of the NESPD. In the estimation that follows, I test for the effects of re-weighting the NESPD data so as to be in line with GHS. By contrast, Table 6 shows slightly higher proportions of females below the threshold in FES compared to GHS. For consistency, the former survey is also re-weighted to be consistent with the latter although this is found to have minimal effects on results.

\section{Estimation and Results}

I adopt a regression-discontinuity design (RD) (Thistlethwaite and Campbell, 1960) to evaluate the relative long-term earnings effects of females eligible to work in the essential war industries and the subsequent post-war female cohorts. This involves exploring wage trajectories of age cohorts affected by conscription and adjacent cohorts who are unaffected after controlling for birth cohort and age effects (Imbens and Lemieux, 2008). RD has recently featured in research into the effects of a legal change in the minimum school leaving age in Britain in 1947 (Oreopolous, 2006; Devereux and Hart, 2008).

The legislation imposed at the start of 1942 to control female civilian employment - the Control of Engagement Order - was revoked in mid-1945. In effect, adult women born before July 1927 were eligible for wartime service while those born during or after this month were exempt. Accordingly, the RD specification is given by 
(1) $\ln W_{i}=\beta_{0}+\beta_{1} I(Y O B \geq J U N E 1927)_{i}+f\left\{Y O B_{i}\right\}+g\left\{A G E_{i}\right\}+\varepsilon_{i}$

where $i$ indexes cohort, $W$ is the real hourly wage, YOB is year of birth, $I($.$) is the$ indicator function, $f\left\{Y O B_{i}\right\}$ is a quartic function of year-of-birth, and $g\left\{A G E_{i}\right\}$ is a quartic function of age.

Since I observe birth year but not birth month, I allow the effects of the legislation to have a different impact for the 1927 cohort (who are partially affected) compared to the earlier cohorts. I also show results for two versions of equation (1). In the first, I simply use the reported data on full-time and part-time females in each data set. In line with the discussion in Section 4, the second specification re-weights the NESPD and FES numbers below PAYE thresholds so as to conform with the reported GHS incidence of these low paid females.

Table 7 shows estimates for 'unadjusted' and ‘adjusted' females aged 40 - 60 in respect of the ending of employment controls in July 1945 - that is $\hat{\beta}_{1}$ in equation (1). There is reasonable consistency across the three data sets and the adjusted set of results differs little from the unadjusted. Compared to females eligible for civilian wartime adult employment there is between a $2 \%$ and $3 \%$ reduction in real wages among the postconscription birth cohorts. Figure 5 provides a graphical illustration. It shows local average log real wage rates plotted for females aged 40 to 60 from the 1975 to 2001 NESPD returns. The fitted line is obtained by regressing the wage averages on a birth 
cohort quartic polynomial and an indicator for the end of adult wartime recruitment in 1927. ${ }^{31}$ The regression is weighted by numbers in each birth cohort.

The NESPD displays the most precisely estimated wage returns. Based on their own work and that of others, Devereux and Hart (2008) compare estimates using the payroll-based NESPD with the GHS and FES household surveys in relation to RD designs estimated in respect of a change in the age of British compulsory school leaving in 1947. Here too it is very clear that the precision of NESPD is far superior.

In the previous section, I give reasons for (a) using different lengths of sample age cohorts and (b) including a somewhat narrow age range in the coverage of wages. I confine attention to estimation using the NESPD so as to obtain adequate sample sizes. Results are shown in Table 8 for the female data re-weighted to match GHS belowthreshold PAYE proportions. ${ }^{32}$ For the 40-60 wage earners, as we move from sample cohorts of \pm 12 years to \pm 3 years around $19271 / 2$, the estimates of the wage advantage to wartime female workers rises monotonically from $2 \%$ to $9 \%$ above their post-war counterparts. Figure 6 shows the polynomial fits for the \pm 6 years age cohorts. As with Figure 5, there is an unequivocal break on either side of the 1928 dividing line. One similarity and one difference is established using the narrower 40-55 age range. In the first place, the estimate for the narrowest cohort range (i.e. \pm 3 years around 19271/2) is the same as for the 40-60 age group. In the second place, the remaining estimated coefficients are all about -0.05 , or a $5 \%$ real wage advantage for war women. Two

\footnotetext{
${ }^{31}$ The break line is 1928. In other words, unlike the results in Table 7, the graphs make no allowance for the fact that conscription effectively ended in mid-1927.

${ }^{32}$ The NESPD proportions shown in Table 5 are adjusted to coincide with the new samples.
} 
tentative conclusions follow. First, the estimated wage advantage of war workers is most pronounced if we limit the sample to 18-21 year olds. Second, there is an overall larger and less variable estimated wage advantage using the 40-55 age range of wage earners.

\section{Robustness Check}

Did conscripted or voluntary service within the essential war industries interfere with the education of women? During the war period the minimum school leaving age was 14 . So it seems unlikely that many women aged 18 and over, who were eligible for conscription or who could volunteer into adult jobs, would have seriously had their years of education curtailed by this wartime event. Soon after the war, in 1947, the minimum school leaving age was raised from 14 to 15 and so the post-war cohorts were affected by this education change.

As a check, I estimated the following RD equation using the GHS data set:

$$
\text { (2) } S C H_{i}=\gamma_{0}+\gamma_{1} I(Y O B \geq J U N E 1927)_{i}+f\left\{Y O B_{i}\right\}+g\left\{A G E_{i}\right\}+\varepsilon_{i}
$$

where SCH is years of schooling. Data limitations led to me use observations \pm 3 years on either side of mid-1927, providing 4781 observations.

The estimate $\hat{\gamma}_{1}$ is 0.15 (standard error $=0.21$ ) indicating an insignificantly small education effect. The British Labour Force Survey (LFS) also provides education information for this period. Table 9 reports LFS and GHS statistics on the age of leaving full-time education and on educational qualifications of three age cohorts of women on either side of the critical pivotal birth year, $1927 .{ }^{33}$ There are some discrepancies

\footnotetext{
${ }^{33}$ Unlike the regression, I make no correction for the 1927 'half year'.
} 
between the two surveys, ${ }^{34}$ but they are generally consistent. By age 18 , over $90 \%$ of females had left full-time education and very large proportions of these had no qualifications. Both surveys show that slightly larger proportions females in the postconscription cohorts stayed in education over the age of 18 and, in line with this, slightly more obtain related qualifications - i.e. degrees and the A-level school leaving certificate or above (A level +). To the extent that schooling-related biases occurred they would have strengthened the wage returns of the post-war cohorts, in which case the earnings returns obtained in respect of wartime service would represent underestimates.

\section{Conclusions}

To the best of my knowledge, this is the first study that attempts to quantify the long term labour market effects of female wartime industrial employment. Commencing in January 1942 and lasting until mid-1945, new adult female entrants on to the British labour market or those females changing jobs were compulsorily directed into employment within essential war industries. Added to this, there were undoubtedly significant elements of voluntary female labour supply into these industries both for patriotic motives as well as to take advantage of relatively high female rates of pay. Many of the resulting job openings involved job tasks and associated skill acquisition that were unavailable to female workers in the pre-war years because, for the most part, women entered a world of work that had previously been dominated by men. The growth of female employment in the vital metal and chemical industries overwhelmingly involved younger women. While difficult to achieve precise estimates, at least $42 \%$ of 18

\footnotetext{
${ }^{34}$ For example, the GHS appears to under-report numbers of women aged 21 and over who continue with full-time education.
} 
to 20 year old females worked in the essential war industries and two-thirds of these owed their jobs to wartime industrial expansion. In contrast, for those women who reached adult working age after mid-1945, job openings and relative pay rates had fallen back towards those experienced in the pre-war female labour market. The resulting comparative advantage of women eligible for civilian wartime industrial service is reflected in the fact that, in the long term, their age cohorts averaged between $2 \%$ and $9 \%$ higher real wage returns than their immediate post-war counterparts. It is likely that the 'true' estimate is towards the upper end of this range. Higher estimated real wage returns are obtained using current income of age ranges that are likely to be more reflective of lifetime income. Also, higher returns are obtained if confining the age cohort sample to the youngest adult female wartime workers.

In April 1947, the minimum school leaving age of British females (and males) was increased from 14 to 15 years. Devereux and Hart (2008) find that this increased the average female leaving age by 0.46 of a year. However, using the NESPD and the RD design, these authors find no effect on real wages of female cohorts affected by this education policy change. This is in sharp contrast to real wage returns arising from widespread participation in essential wartime industries some 5 years earlier. While acknowledging special circumstances and features, the sharp wartime increase in vocational training among females resulted in far greater long-term economic benefits than increased compulsory school training. 


\section{References}

Acemoglu, D, D H Autor and D Lyle. 2004. Women, war, and wages: the effect of female labor supply on the wage structure at midcentury. Journal of Political Economy 112, 497-551.

Angrist, J D. 1990. Lifetime earnings and the Vietnam era draft lottery: evidence from social security administrative records. American Economic Review 80, 313-336.

Card, D. 1999. The causal effect of education on earnings. Handbook of Labor Economics, Volume 3A, North-Holland.

Devereux, P J and R A Hart. 2008. Forced to be rich? Returns to compulsory schooling in Britain. IZA, Discussion Paper \# 3305.

Douie, V. 1950. Daughters of Britain. Oxford: George Ronald.

Fernández, R, A Fogli and C Olivetti. 2004. Mothers and sons: preference formation and female labor force dynamics. Quarterly Journal of Economics 119, 1249-1299.

Haider, S and G Solon. 2006. Life-cycle variation in the association between current and lifetime earnings. American Economic Review 96, 1278-1296.

Hart, R.A. 2007. Women doing men’s work and women doing women’s work: female work and pay in British wartime engineering. Explorations in Economic History 44, 114-130.

Howlett, P. 1995. Fighting with figures. London: HMSO.

Imbens, G and T Lemieux. 2008. Regression discontuity designs: a guide to practice. Journal of Econometrics 142, 615-635.

Inman, p. 1957. Labour in the munitions industries. London: Longman, Green and Co. 
International Labour Office. 1946. The war and women's employment. The experience of the United Kingdom and the United States. Montreal: ILO.

Ministry of Labour and National Service. 1944. Statistics relating to the war effort of the United Kingdom. Command 6564. London: HMSO.

Ministry of Labour and National Service. 1947. Report for the years 1939-1946. Command 7225. London: HMSO.

Oreopoulos, P. 2006. Estimating average and local average treatment effects of education when compulsory schooling laws really matter. American Economic Review 96, 152-175.

Parker, H.M.D. 1957. Manpower: a study of war-time policy and administration. London: Longman, Green and Co.

Smith, H.L. 1981. The problem of “equal pay for equal work” in Great Britain during World War II. Journal of Modern History 53, 652-672.

Smith, H.L. 1984. The womanpower problem in Britain during the Second World War. The Historical Journal 27, 925-945.

Thistlethwaite, D.L. and D.T. Campbell. 1960. Regression-discontinuity analysis: an alternative to the ex post facto experiment. Journal of Educational Psychology 51, 309-317. 


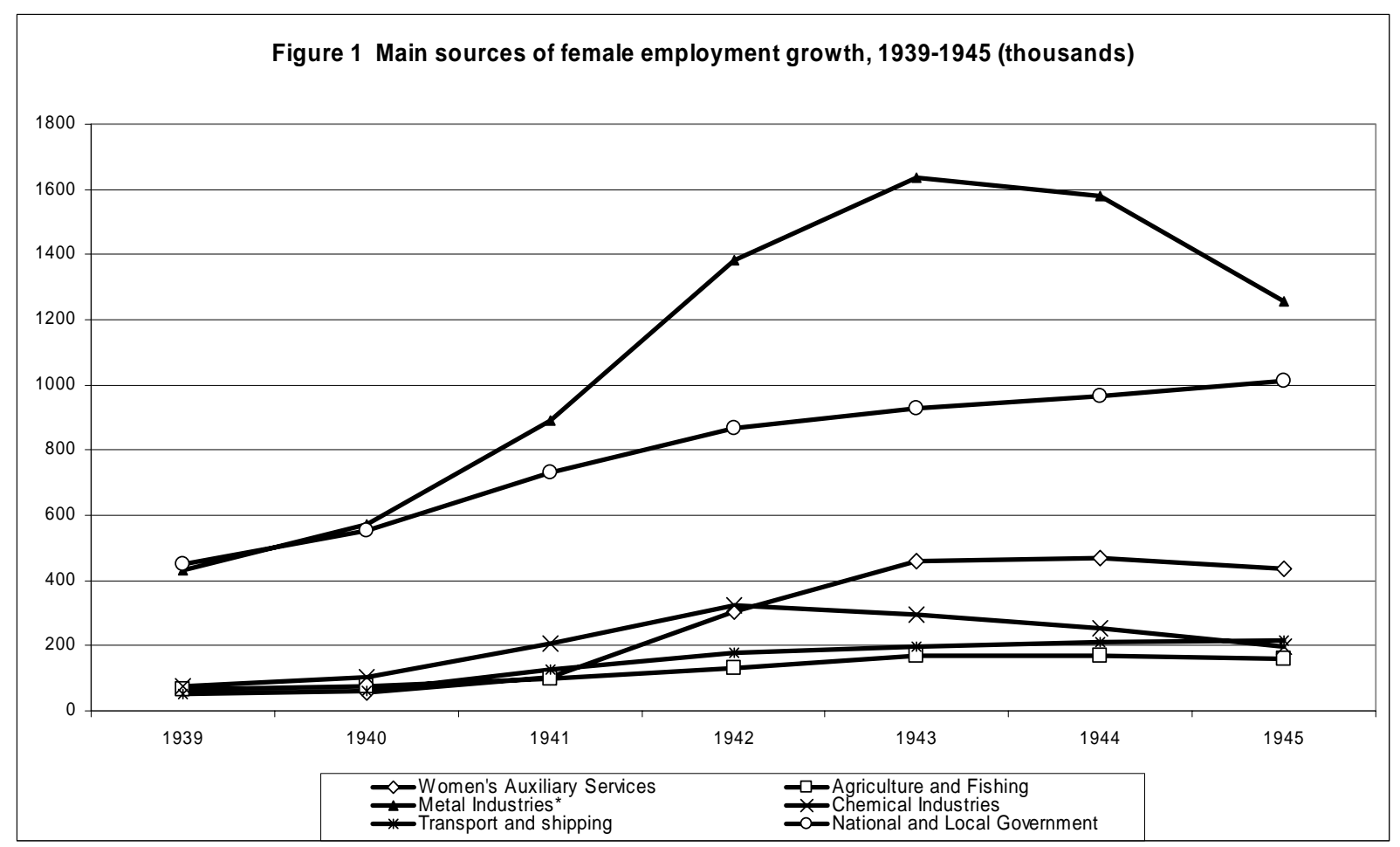

Source: Parker (1957, Table 1). *Metal industries cover metal manufacture, engineering, motors, aircraft and other vehicles, shipbuilding and ship-repairing, metal goods, etc. Women in industrial parttime employment are included with two part-timers being counted as one full-time equivalent. 


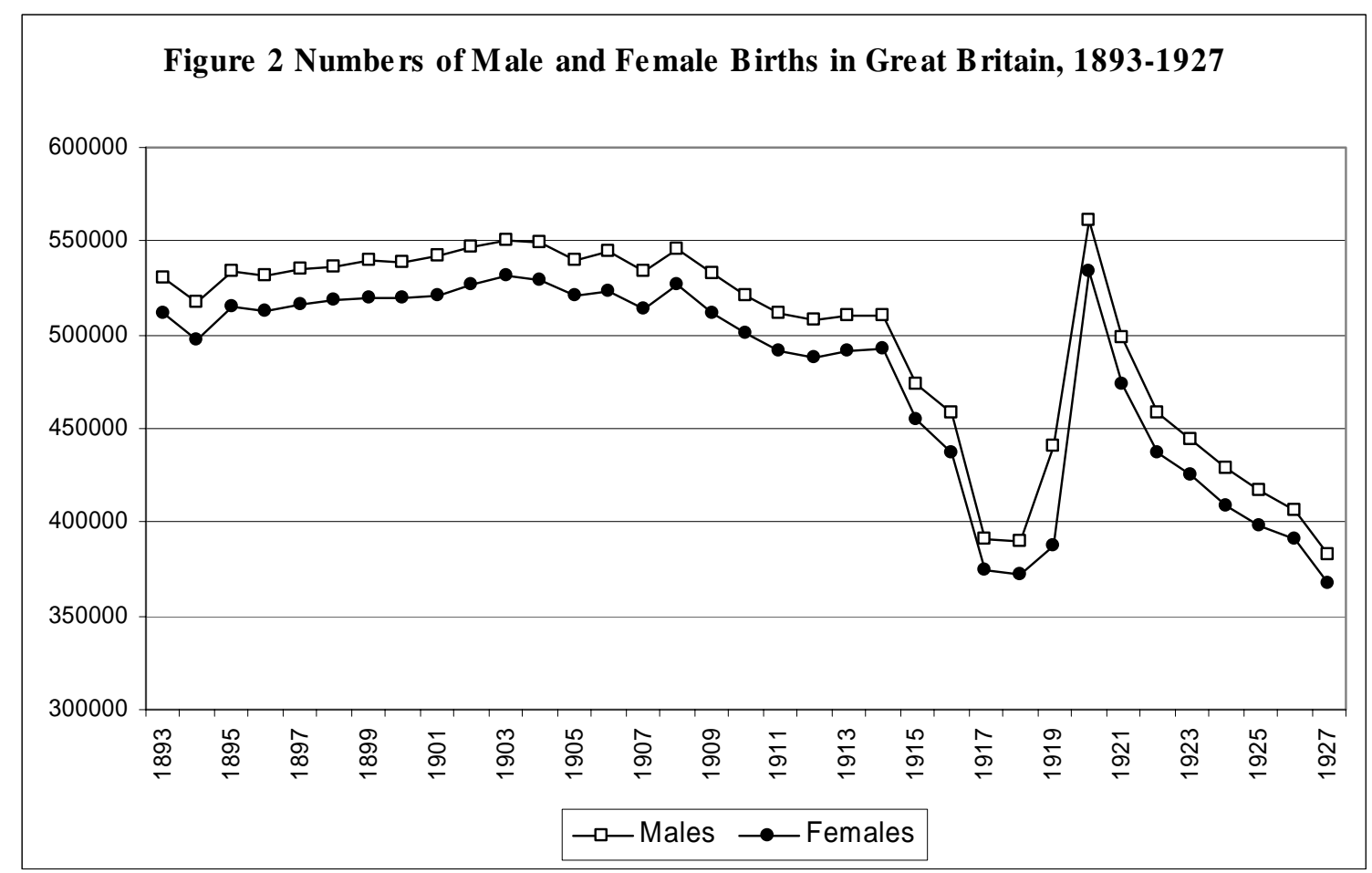

Sources: For 1838 to 1983, birth statistics for England and Wales obtained from Office for National Statistics, Birth Statistics 1937-1983. Birth statistics for Scotland are obtained from General Register Office for Scotland, gro-scotland.gov.uk

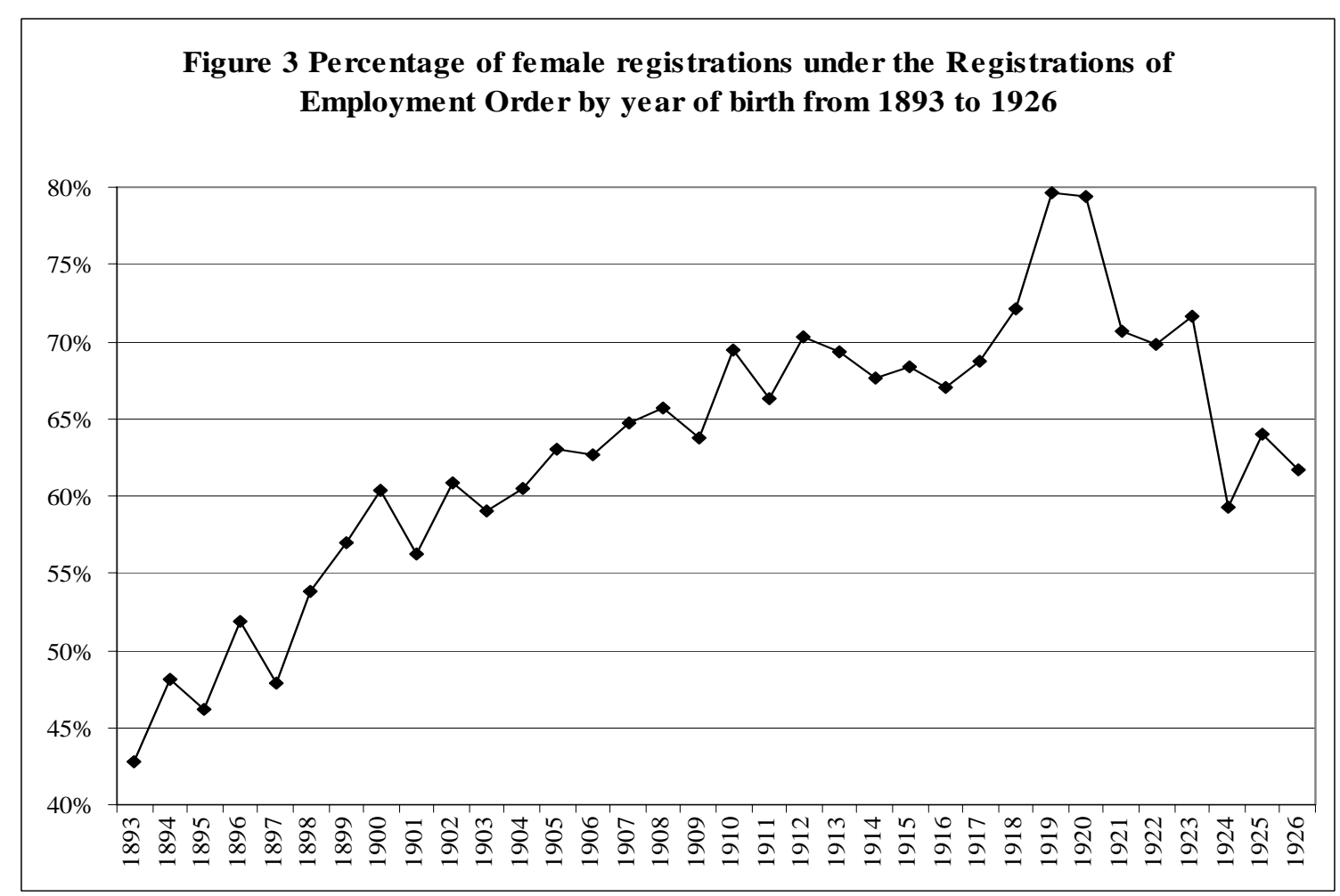




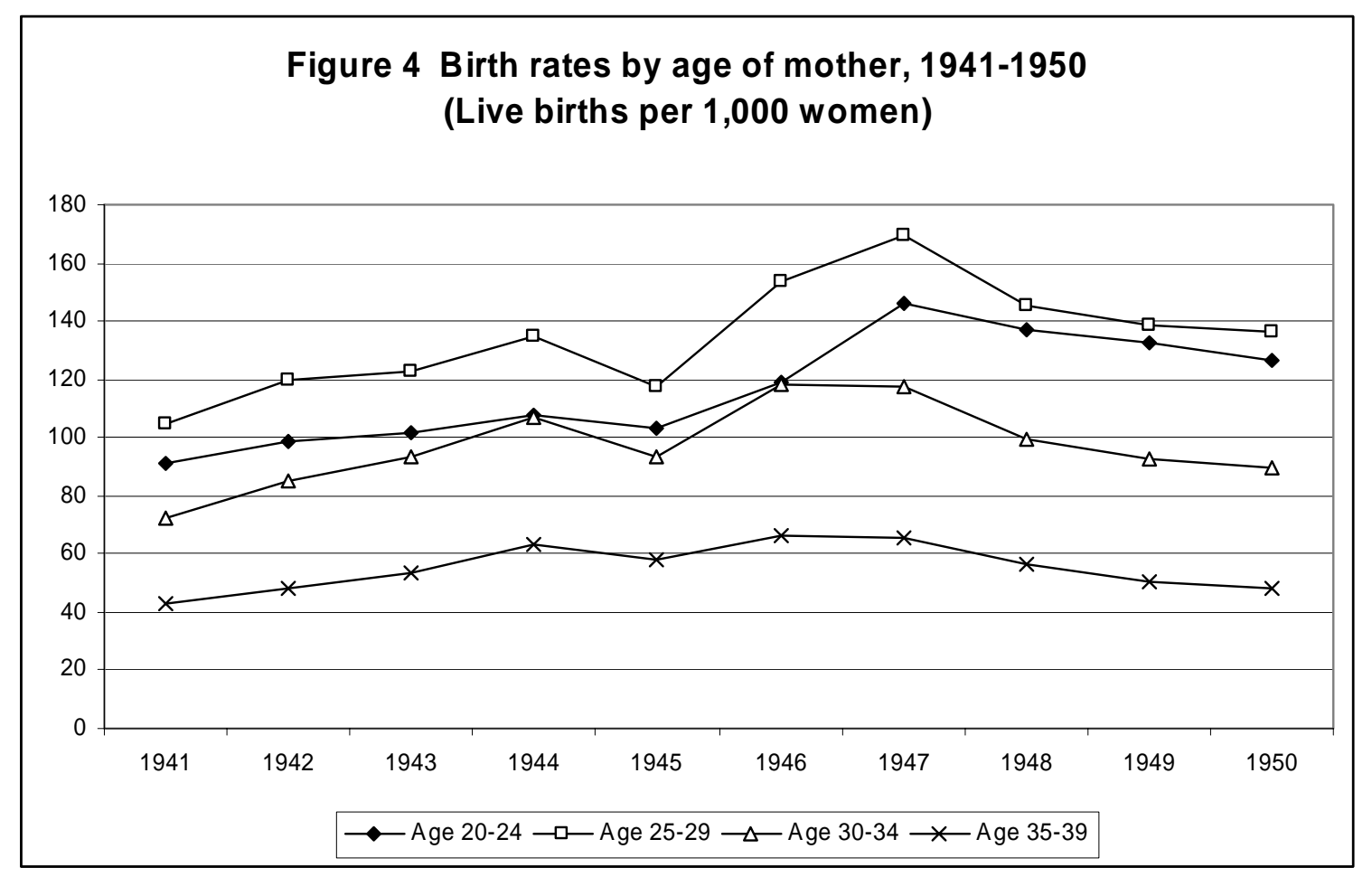

Figure 5 Average hourly basic pay of women aged 40 to 60 by 1917 to 1937 birth cohorts (NESPD)

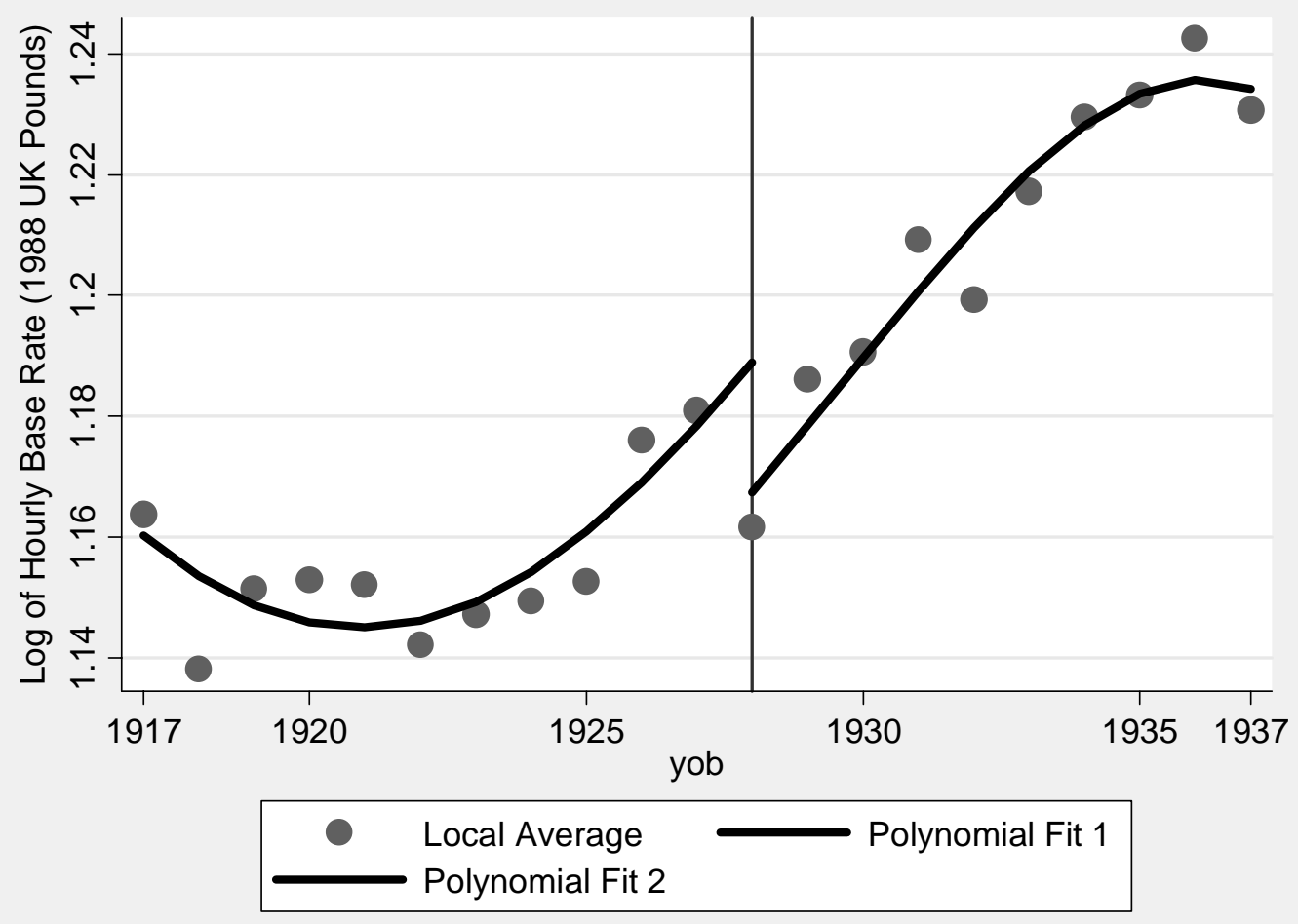


Figure 6 Average hourly basic pay of women aged 40 to 60 by 1921 to 1933 birth cohorts (NESPD)

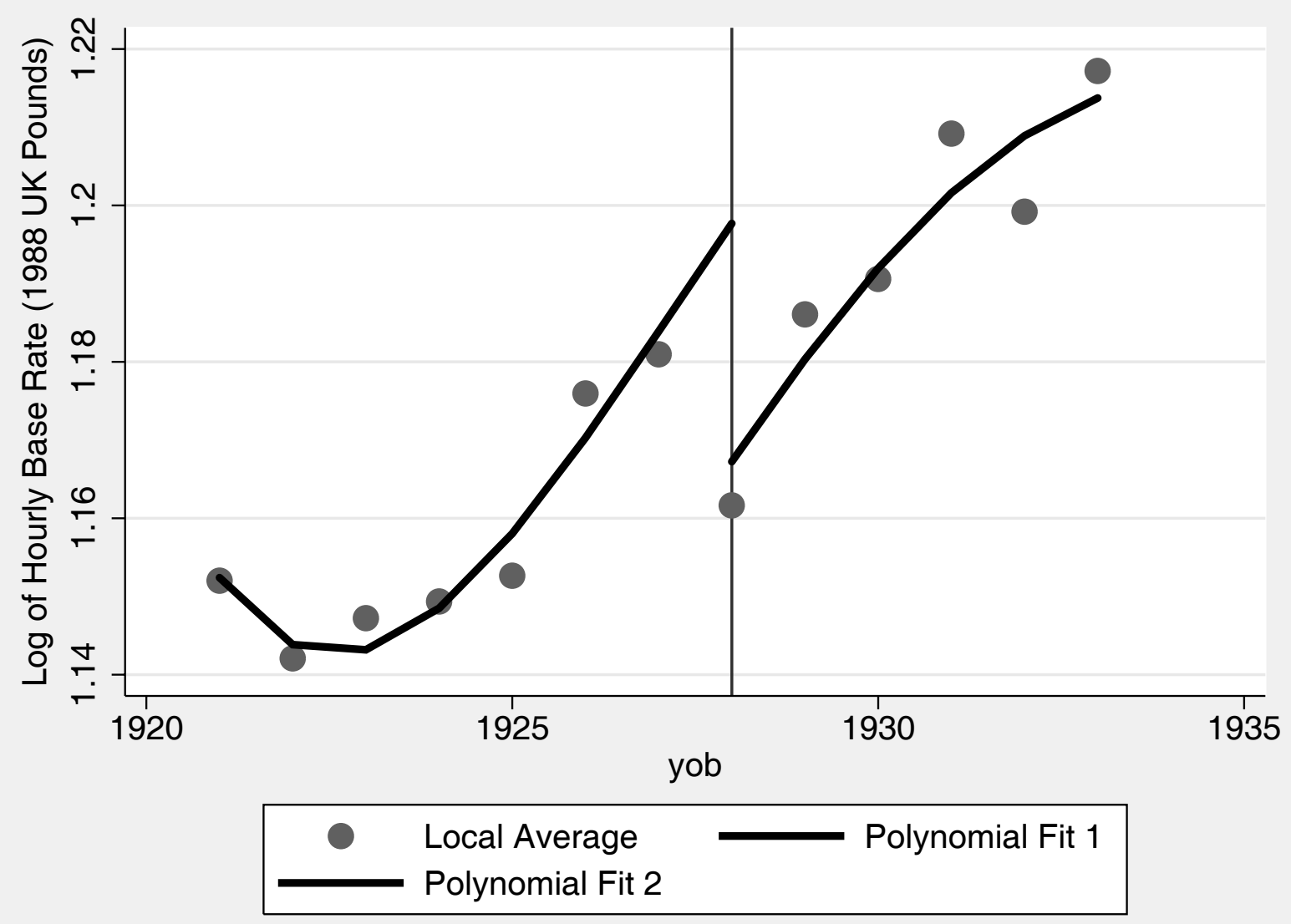


Table 1 Male and Female Engagement in Armed Forces, Civil Defence and Industry: 1939 - 1946

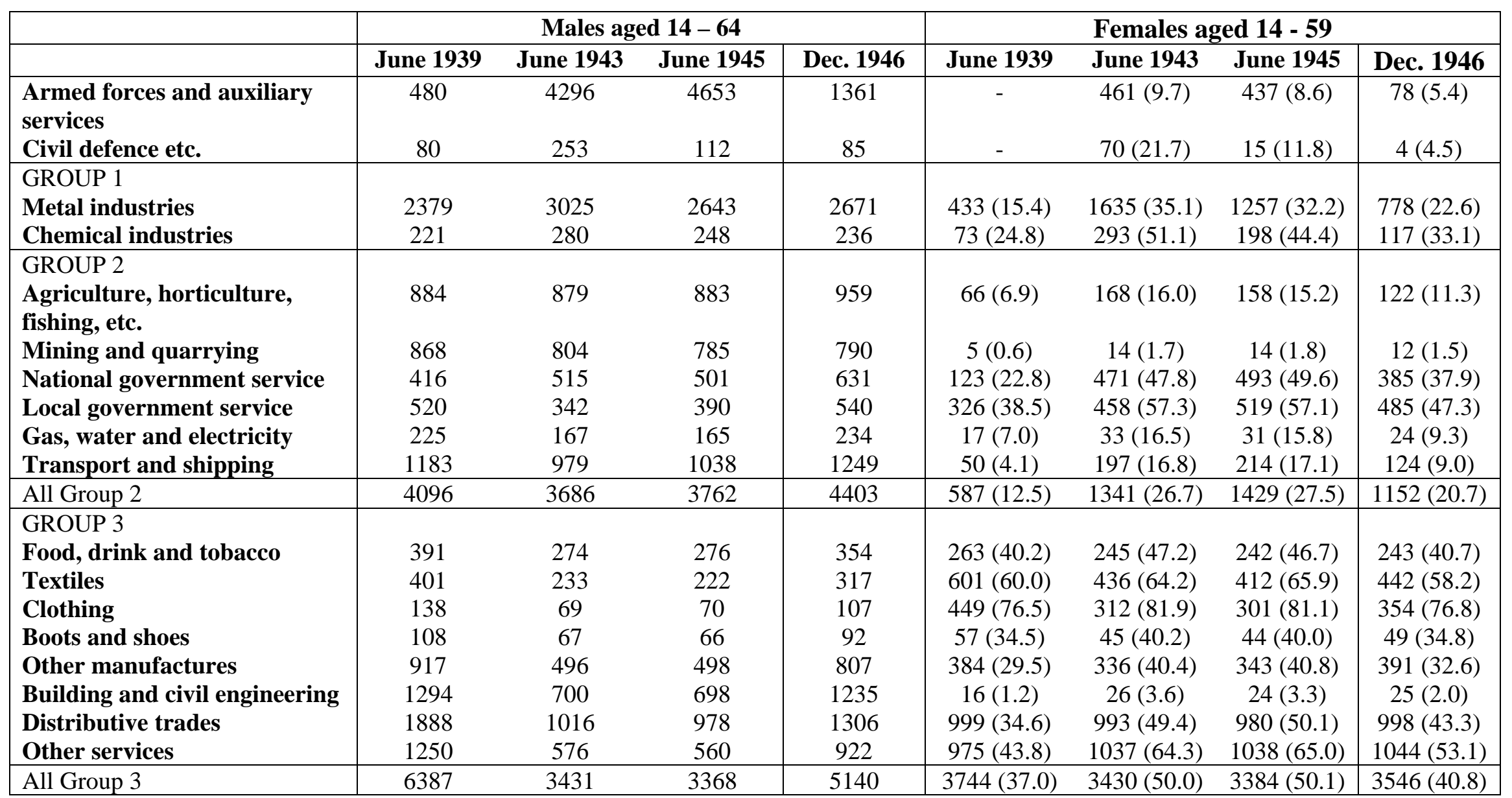

Source: MLNS (1947, p. 350). Figures in brackets show percentage shares of female to total employment. The statistics for females count two part-time women as equivalent to one unit. Data include self-employed. 
Table 2 Net changes in the civilian workforce aged 18 to 51: 1942-45 compared to 1937 after adjusting for changes in the birth rates

\begin{tabular}{|c|c|c|c|c|c|}
\hline & & & & \multicolumn{2}{|c|}{ (Thousands) } \\
\hline $\begin{array}{l}\text { Age- } \\
\text { Group }\end{array}$ & 1937 & 1942 & 1943 & 1944 & 1945 \\
\hline & $\begin{array}{c}\text { Actual numbers } \\
\text { insured }\end{array}$ & \multicolumn{4}{|c|}{ Net changes compared to 1937 (adjusted for birth rates } \\
\hline & \multicolumn{5}{|c|}{ Males } \\
\hline 18 to 20 & 757 & -285 & -391 & -394 & -376 \\
\hline 21 to 25 & 1564 & -902 & -969 & -993 & -957 \\
\hline 26 to 30 & 1525 & -610 & -659 & -681 & -711 \\
\hline 31 to 35 & 1368 & -260 & -358 & -402 & -450 \\
\hline 36 to 40 & 1118 & 31 & -21 & -63 & -96 \\
\hline 41 to 45 & 935 & 119 & 126 & 139 & 126 \\
\hline \multirow[t]{2}{*}{46 to 50} & 856 & 50 & 58 & 50 & 36 \\
\hline & \multicolumn{5}{|c|}{ Females } \\
\hline 18 to 20 & 567 & 159 & 123 & 143 & 154 \\
\hline 21 to 25 & 828 & 330 & 217 & 180 & 136 \\
\hline 26 to 30 & 556 & 255 & 234 & 179 & 115 \\
\hline 31 to 35 & 378 & 236 & 276 & 230 & 168 \\
\hline 36 to 40 & 286 & 222 & 266 & 236 & 195 \\
\hline 41 to 45 & 211 & 184 & 241 & 241 & 212 \\
\hline 46 to 50 & 154 & 114 & 164 & 172 & 158 \\
\hline
\end{tabular}

Notes: Figures on insured employees are based on statistics in MLNS, 1947, p. 260. For birth rate sources see Figure 2. The numbers in the 1942 to 1945 columns are adjusted to account for changes in the birthrates across the age cohorts. For example, there were 757,000 insured males aged 18 to 20 in 1937. These were born between 1917 and 1919. In 1942, there were 560,000 insured males, born between 1922 and 1924. The number of births between 1922 and 1924 was 1.1168 of those between 1917 and 1919 .

Therefore, assuming equivalent proportions of insured workers to total births through time, this translates to 845,000 insured workers in 1942, adjusted for the rise in the birth rate (i.e. 757,000 $\times 1.1168$ ). The difference between actual insured numbers and those corrected for the birth rate (i.e. 560,000 - 845,000 = 285,000 ) represents the estimated drop in the insured employed due to military call-up. 
Table 3 Female Employment Changes by 18-40 and 41-59 Age Groups in the Auxiliary Services and in Group 1, Group 2 and Group 3 Industries (Mid 1939 - Mid 1943)

(Thousands)

\begin{tabular}{|lccc|}
\hline Age Group & $\begin{array}{c}\text { Auxiliary Services } \\
\text { and Group 1 } \\
\text { industries }\end{array}$ & Group 2 industries & Group 3 industries \\
\hline $\mathbf{1 8 - 4 0}$ & 344 & 565 & 2,175 \\
\hline Mid-1939 & 1,935 & 1,086 & 1,651 \\
Mid-1943 & $+1,591$ & +521 & -524 \\
Change & 40 & 192 & 636 \\
\hline $\mathbf{4 1 - 5 9}$ & 335 & 366 & +287 \\
\hline Mid-1939 & +295 & +174 & \\
\hline Mid - 1943 & & & \\
\hline
\end{tabular}

Source: Ministry of Labour Gazette (1944), p. 197. 
Table 4 Estimated Percentages of Female Age Cohorts Working in Group 1 and Group 2 Industries in mid- 1943 and in mid-1943 compared to mid-1939

\begin{tabular}{|c|c|c|c|c|c|c|c|}
\hline Age group & $\begin{array}{c}\text { Proportion of } \\
1943 \text { insured } \\
\text { workforce aged } \\
18 \text { - } 40\end{array}$ & $\begin{array}{c}\text { Estimated share } \\
\text { of } 1943 \text { total } \\
\text { Group } 1 \text { and } 2 \\
\text { employment }\end{array}$ & $\begin{array}{c}\text { Estimated share } \\
\text { of Group } 1 \text { and } 2 \\
\text { employment } \\
\text { increase, mid } \\
1939 \text { to mid } 1943\end{array}$ & $\begin{array}{l}\text { Numbers born } \\
\text { by age group }\end{array}$ & $\begin{array}{c}\text { Total Group } 1 \\
\text { and } 2 \\
\text { employment as } \\
\% \text { of births } \\
{[(3) /(5)] \times 100}\end{array}$ & $\begin{array}{c}\text { Group } 1 \text { and } 2 \\
\text { increase in } \\
\text { employment as } \\
\% \text { of births } \\
{[(4) /(5)] \times 100}\end{array}$ & $\begin{array}{l}\text { (6) plus \% share } \\
\text { of females in } \\
\text { Auxiliary } \\
\text { Services }\end{array}$ \\
\hline (1) & (2) & (3) & (4) & (5) & (6) & (7) & (8) \\
\hline 18 to 20 & 0.202 & 521,806 & 338,188 & $1,232,175$ & 42.3 & 27.5 & 52.0 \\
\hline 21 to 25 & 0.271 & 700,047 & 453,708 & $2,204,032$ & 31.8 & 20.6 & 42.5 \\
\hline 26 to 30 & 0.199 & 514,057 & 333,166 & $2,251,122$ & 22.8 & 14.8 & 25.1 \\
\hline 31 to 35 & 0.176 & 454,643 & 294,659 & $2,517,446$ & 18.1 & 11.7 & 19.0 \\
\hline 36 to 40 & 0.152 & 392,646 & 254,478 & $2,617,362$ & 15.0 & 9.7 & 15.4 \\
\hline
\end{tabular}

Notes: Employment weights in column (2) are obtained form MLNS (1947, p.260). The figures in column (3) are arrived at by applying the insured employment weights in column (2) to a total of 3,021,000 estimated total employment of 18-40 year olds in Group 1, Group 2 industries and Auxiliary Services in Table 3. Auxiliary services numbers by age range are then substracted out using data in Howlett (1995, Table 3.5), leaving a total of 2,583,200 of 18-40 year olds in Group 1 and Group 2 industries. Similarly, the weights are applied to a total increased employment of 1,674,200 to obtain column (4). Sources of birth numbers in column (5) are shown in Figure 2. 
Table 5 Percentage increases in average hourly and weekly earnings of men and women, October 1938 to January 1944

\begin{tabular}{|c|c|c|c|c|}
\hline \multirow[t]{2}{*}{ Industries } & \multicolumn{2}{|c|}{ Men } & \multicolumn{2}{|c|}{ Women } \\
\hline & Hourly & Weekly & Hourly & Weekly \\
\hline Metal, engineering and shipbuilding & 70 & 89 & 105 & 115 \\
\hline Chemical, paint, oil etc. & 57 & 73 & 98 & 100 \\
\hline Miscellaneous manufacturing & 69 & 83 & 93 & 96 \\
\hline
\end{tabular}

Source: Ministry of Labour Gazette, Aug. 1944, pp. 126-128.

Table 6 Proportions of women aged 40 to 60 below the PAYE thresholds

\begin{tabular}{|c|c|c|c|}
\hline & NESPD & GHS & FES \\
\hline 1975 & 8.2 & & 27.24 \\
\hline 1976 & 7.7 & & 22.65 \\
\hline 1977 & 12.4 & & 30.99 \\
\hline 1978 & 11.01 & & 27.07 \\
\hline 1979 & 13.15 & 25.54 & 29.99 \\
\hline 1980 & 12.95 & 25.82 & 26.83 \\
\hline 1981 & 10.46 & 21.88 & 27.49 \\
\hline 1982 & 12.53 & 25.19 & \\
\hline 1983 & 14.22 & 25.41 & \\
\hline 1984 & 16.04 & 28.81 & \\
\hline 1985 & 17.55 & 30.58 & \\
\hline 1986 & 17.45 & 29.85 & \\
\hline 1987 & 16.42 & 29.39 & \\
\hline 1988 & 16.71 & 27.26 & \\
\hline 1989 & 15.43 & 25.36 & \\
\hline 1990 & 16.57 & 25.38 & \\
\hline 1991 & 16.56 & 25.07 & \\
\hline 1992 & 17.52 & 25.4 & \\
\hline 1993 & 17.36 & 24.68 & \\
\hline 1994 & 16.95 & 23.53 & \\
\hline 1995 & 18.41 & 23.03 & \\
\hline 1996 & 18.69 & 24.00 & \\
\hline 1997 & 22.95 & & \\
\hline 1998 & 27.62 & & \\
\hline Mean & 13.32 & 25.90 & 27.38 \\
\hline
\end{tabular}

Source: Annual Abstract of Statistics 
Table 7 Effect of ineligibility for adult war work on female log hourly wage rates

\begin{tabular}{|c|c|c|}
\hline & $\begin{array}{c}\text { Females } \\
\text { (ages 40-60) }\end{array}$ & $\begin{array}{l}\text { Adjusted Females } \\
\text { (ages 40-60) }\end{array}$ \\
\hline & (19271/2 \pm 10 years) & (19271/2 \pm 10 years) \\
\hline NESPD & $\begin{array}{l}-0.021^{*} \\
(0.005)\end{array}$ & $\begin{array}{l}-0.027^{*} \\
(0.005)\end{array}$ \\
\hline GHS & $\begin{array}{l}-0.031 \\
(0.024)\end{array}$ & $\begin{array}{l}-0.031 \\
(0.024)\end{array}$ \\
\hline FES & $\begin{array}{l}-0.028 \\
(0.020)\end{array}$ & $\begin{array}{l}-0.022 \\
(0.022)\end{array}$ \\
\hline $\begin{array}{l}\text { Observations } \\
\text { NESPD } \\
\text { GHS } \\
\text { FES }\end{array}$ & $\begin{array}{c}286,255 \\
14,028 \\
9,204\end{array}$ & $\begin{array}{c}286,255 \\
14,028 \\
9,204\end{array}$ \\
\hline
\end{tabular}

Standard errors in brackets. * denotes statistically significant at $1 \%$ level.

Each regression includes both a quartic birth cohort controls and quartic age controls.

Conscription dummies apply to birth cohorts 1918 - 1937 and take the value 0 if year < 1927, 0.5 if year $=1927$, and 1 if year $>1927$.

The adjusted female results in the last column report weighted NESPD and FES regressions. For NESPD, weight $=[$ NESPD annual proportion of females under PAYE threshold/mean GHS proportion under threshold]. FES adjusted results are based on an equivalent calculation. (See Table 7 for proportions.)

Coverage and construction of wage and earnings data are as follows. NESPD, 1975 2001. Wage $=$ [basic weekly wage (excluding overtime)/actual weekly basic hours] . GHS, $1972-1978$. Wage earnings = [weekly rate of pay/no. of hours usually worked excluding meals and overtime] FES, 1970 - 1981. Wage earnings = [gross weekly wage/actual hours excluding meals but including overtime]. 
Table 8 Effects of varying sample cohort lengths and wage age bands [NESPD]

\begin{tabular}{|c|c|c|}
\hline & Ages 40-60 & Ages 40-55 \\
\hline $19271 / 2 \pm 12$ years & $\begin{array}{c}-0.019 * \\
(0.005) \\
{[333,289]}\end{array}$ & $\begin{array}{c}-0.055 * \\
(0.007) \\
{[245,239]}\end{array}$ \\
\hline $19271 / 2 \pm 10$ years & $\begin{array}{c}-0.027^{*} \\
(0.005) \\
\\
{[286,255]}\end{array}$ & $\begin{array}{c}-0.050 * * \\
(0.007) \\
{[208,787]}\end{array}$ \\
\hline $19271 / 2 \pm 6$ years & $\begin{array}{c}-0.039 * \\
(0.007) \\
\\
{[183,731]}\end{array}$ & $\begin{array}{c}-0.052 * \\
(0.008) \\
{[134,856]}\end{array}$ \\
\hline $19271 / 2 \pm 3$ years & $\begin{array}{c}-0.087 * \\
(0.017) \\
{[100,772]}\end{array}$ & $\begin{array}{c}-0.088^{*} \\
(0.019) \\
{[74,989]}\end{array}$ \\
\hline
\end{tabular}

Standard errors in ( ) brackets, number of observations in [ ] brackets. * denotes significant at $1 \%$

Each regression includes both quartic birth cohort controls and quartic age controls

All results are in respect of females adjusted to conform with the GHS weights in respect of PAYE returns 
Table 9 Female education and qualifications of eligible and not-eligibleage cohorts (LFS and GHS)

\begin{tabular}{|c|c|c|c|c|}
\hline & \multicolumn{2}{|c|}{ LFS } & \multicolumn{2}{|c|}{ GHS } \\
\hline & 1925-1927 & 1928-1930 & 1925-1927 & 1928-1930 \\
\hline \multicolumn{5}{|c|}{ Age when finishing full-time education (proportions) } \\
\hline No education & 0.18 & 0.12 & 0.55 & 0.50 \\
\hline $6-13$ & 2.89 & 2.15 & 4.67 & 2.74 \\
\hline 14 & 63.40 & 59.65 & 67.89 & 64.68 \\
\hline $15-17$ & 27.18 & 29.16 & 24.01 & 27.80 \\
\hline 18 and over & 6.35 & 8.93 & 2.87 & 4.28 \\
\hline \multicolumn{5}{|c|}{ Qualifications (proportions) } \\
\hline Degree & 1.06 & 1.85 & 1.13 & 1.76 \\
\hline A level + & 4.72 & 7.88 & 6.77 & 7.83 \\
\hline O level + & 7.13 & 12.90 & 15.40 & 19.60 \\
\hline No qualifications & 87.09 & 77.37 & 76.65 & 70.80 \\
\hline
\end{tabular}

